\title{
MOKYTOJŲ NUOMONĖ APIE JŲ IR JŲ MOKINIŲ SVEIKATOS STIPRINIMO INFORMACIJOS POREIKI
}

\author{
Rūta Maceinaitė, Genẻ Šurkienė, Rita Sketerskienė, Mindaugas Butikis \\ Vilniaus universiteto Medicinos fakulteto Sveikatos mokslu instituto Visuomenés sveikatos katedra
}

Raktažodžiai: mokytojai, mokiniai, sveikatos stiprinimas, informacijos apie sveikatos stiprinimą poreikis.

\section{Santrauka}

Mokykla yra tinkamiausia vieta mokinių sveikatos stiprinimo procesui, kuris teikia daugiau galimybiu rūpintis savo sveikata bei ją gerinti. Sveikatos stiprinimas duoda geriausius rezultatus tuomet, kai i procesą įsitraukia ne tik mokiniai, bet ir jų mokytojai, tad akivaizdu, kad sveikatos stiprinimo sèkmè priklauso nuo mokytojo požiūrio ị ši procesą ir šios srities žinių. Tyrimo tikslas - ịvertinti mokytojų nuomonę apie jų ir jų mokinių sveikatos stiprinimo informacijos poreiki. Atliktas momentinis tyrimas, kurio metu apklausti 1247 devintokams bei dešimtokams dèstantys mokytojai iš 110 įvairių Lietuvos mokyklų. Paplitimo ịverčiams apskaičiuoti 95 proc. pasikliautinieji intervalai (toliau - PI), sudaryti logistinès regresijos modeliai, gauti pakoreguoti šansų santykiai (toliau ŠS), apskaičiuoti jų PI (95 proc.). Tyrimo rezultatai atskleide, kad 44,3 proc. mokytojų gauna pakankamai informacijos apie mokinių sveikatos stiprinimą, 43,3 proc. nori daugiau informacijos šia tema. Šansas gauti pakankamai informacijos apie mokinių sveikatos stiprinimą yra reikšmingai susijęs su mokytojų išsilavinimu, mokyklos buvimu sveikatą stiprinančių mokyklų (toliau - SSM) tinkle bei mokyklos vieta, o šansas gauti dar daugiau informacijos - su mokytoju amžiumi ir dèstomu dalyku. Nustatyta, kad mokytojams reikalingiausia informacija apie sveiką mitybą. Jie mano, kad informacija šia tema reikalingiausia ir jų mokiniams. Mokytojų nuomone, jų mokiniams labiausiai trūksta informacijos apie protinę sveikatą. Rezultatai parodè, kad daugumą (71,6 proc.) apklaustụjų domina informacija apie mokinių sveikatos stiprinimą ir kad daugiau kaip pusė respondentų $(62,9$ proc.) patys ieškojo informacijos šia tema. Domejjimasis reikšmingai susijęs su lytimi, dèstomu dalyku, darbu SSM, o informacijos paieška - su mokytojų išsilavinimu, dèstomu dalyku, mokyklos vieta bei mokyklos buvimu SSM tinkle.

\section{Ivadas}

Vaikų sveikata - investicija ị rytojaus visuomenę. Gera vaikų sveikatos būklè turi būti vienas iš didžiausių bet kurios visuomenès siekinių, nes šių dienų vaikų sveikatos problemos lemia visos visuomenès problemas ateityje, o puiki vaikų sveikatos būklè garantuoja tvarią visuomenès gyvenimo kokybès raidą [1,2].

Mokykla užima itin svarbią vietą vaiko gyvenime. Vaikai labai didelę laiko dalį praleidžia ugdymo ịstaigoje, tad mokykla yra svarbi aplinka vykdyti ịvairias sveikatos stiprinimo priemones, kurios ateityje turès esmini poveiki suaugusio žmogaus sveikatai $[3,4]$. Mokykla yra itin tinkama vieta sveikatos stiprinimui - procesui, teikiančiam daugiau galimybių rūpintis savo sveikata ir ją gerinti [5]. Sveikatos stiprinimo procesas mokykloje gerina vaikų gebejjimus imtis veiksmų ir daryti pokyčius, vaikai igalinami patys tvarkyti savo gyvenimą $[3,5]$. Svarbu tai, kad mokykloje skiriant dideli dèmesị mokinių sveikatos stiprinimui, teigiamas poveikis daromas visų mokinių sveikatai, neatsižvelgiant ị jų socioekonominę padètį [4]. Geriausių sveikatos stiprinimo rezultatų galima tikètis tuomet, kai visi mokyklos bendruomenès nariai (mokiniai, jų tėvai, mokytojai ir kiti darbuotojai) domėsis sveikatos stiprinimu, ieškos informacijos apie tai, keisis turima informacija, dalinsis nuomonemis ir ịžvalgomis bei įvairiais būdais dalyvaus sveikatos stiprinimo veikloje [6-8].

Sveikatos stiprinimo proceso sẻkmé mokykloje nemenka dalimi priklauso nuo mokytojo. Neretai mokytojas apibūdinamas kaip „mokinių sveiko gyvenimo būdo kūrèjas“. Nuo mokytojo požiūrio ị sveikatos stiprinimą ir jo turimų žinių priklauso, kaip jis prisidès prie mokinių sveikatos stiprinimo, kaip skatins juos tausoti sveikatą $[9,10]$. UNICEF duomenimis, Lietuvos šeimose tèvai su vaikais per parą bendrauja tik apie 7 minutes, todèl galima daryti prielaidą, kad mokytojai yra labai svarbus informacijos apie sveikatos stiprinimą 
šaltinis [11]. Šio tyrimo tikslą lèmė mokslinių tyrimų apie mokytojų sveikatos stiprinimo informacijos poreikį stoka.

Tyrimo tikslas - įvertinti mokytojų nuomonę apie jų ir jų mokinių sveikatos stiprinimo informacijos poreikį.

1 lentelè. Respondentų charakteristika

\begin{tabular}{|c|c|c|}
\hline Požymiai & \begin{tabular}{|c|} 
Respondentų \\
skaičius
\end{tabular} & $\begin{array}{l}\text { Respondenty } \\
\text { dalis (proc.) }\end{array}$ \\
\hline \multicolumn{3}{|l|}{ Mokyklos tipas } \\
\hline Pagrindinė & 498 & 39,9 \\
\hline Gimnazija & 749 & 60,1 \\
\hline \multicolumn{3}{|l|}{ Mokyklos vieta } \\
\hline Miestas, didysis miestas & 584 & 46,8 \\
\hline Kaimas, miestelis & 663 & 53,2 \\
\hline \multicolumn{3}{|l|}{$\begin{array}{l}\text { Mokyklos priklausymas SSM } \\
\text { tinklui }\end{array}$} \\
\hline Priklauso & 513 & 41,1 \\
\hline Nepriklauso & 734 & 58,9 \\
\hline \multicolumn{3}{|l|}{ Lytis } \\
\hline Vyras & 169 & 13,6 \\
\hline Moteris & 1078 & 86,4 \\
\hline \multicolumn{3}{|l|}{ Išsilavinimas } \\
\hline Aukštasis & 1207 & 96,8 \\
\hline Specialusis, aukštesnysis & 40 & 3,2 \\
\hline \multicolumn{3}{|l|}{ Amžius } \\
\hline Iki $50 \mathrm{~m}$. & 549 & 44,0 \\
\hline $50 \mathrm{~m}$. ir daugiau & 698 & 56,0 \\
\hline \multicolumn{3}{|l|}{ Déstomas dalykas } \\
\hline Humanitarinis & 506 & 40,6 \\
\hline Tikslusis & 372 & 29,8 \\
\hline Kitas & 369 & 29,6 \\
\hline
\end{tabular}

2 lentelè. Veiksniai, darantys poveikị sveikatos stiprinimo informacijos gavimui

$N=1247$. Modelio tiketinumo santykio chi kvadratas 59,47; lls. 4; $p<0,0005$; HosmerLemeshow testo chi kvadratas 1,59; llsk. 5; $p=0,903 ; R 2$ 0,0029.

\begin{tabular}{|l|c|c|c|c|}
\hline Kintamieji & $\begin{array}{c}\text { ŠS } \\
\text { (ben- } \\
\text { drasis) }\end{array}$ & $\begin{array}{c}\text { ŠS } \\
\text { (kore- } \\
\text { guotas) }\end{array}$ & PI (95\%) & $\begin{array}{c}\text { p } \\
\text { reikš- } \\
\text { mé }\end{array}$ \\
\hline $\begin{array}{l}\text { Mokyklos tipas } \\
\text { Gimnazija } \\
\text { Pagrindine }\end{array}$ & 1,00 & & & \\
\hline $\begin{array}{l}\text { Mokytojo išlavinimas } \\
\text { Specialusis, aukštes- } \\
\text { nysis, aukštasis }\end{array}$ & 1,29 & 1,23 & 0,$97 ; 1,56$ & 0,075 \\
\hline $\begin{array}{l}\text { Mokyklos vieta } \\
\text { Miestas, }\end{array}$ & 2,45 & 2,85 & 1,$36 ; 5,97$ & 0,006 \\
didysis miestas & 1,00 & & & \\
Kaimas, miestelis & 1,41 & 1,29 & 1,$03 ; 1,64$ & 0,027 \\
\hline $\begin{array}{l}\text { Mokyklos priklausy- } \\
\text { mas SSM tinklui }\end{array}$ & 1,00 & & & \\
Nepriklauso & & & \\
Priklauso & 2,14 & 2,08 & 1,$65 ; 2,63$ & $<0,0005$ \\
\hline
\end{tabular}

\section{Tyrimo medžiaga ir metodai}

Momentinis tyrimas atliktas anoniminès anketinès apklausos būdu. Originali anketa parengta naudojantis Sveikatą stiprinančių mokyklų veiklos vertinimo praktiniame vadove pateiktais klausimais [12]. Anketa pakoreguota, atsižvelgiant i bandomojo tyrimo rezultatus. Galutineje anketoje pateikti 66 klausimai.

SSM bei šiam tinklui nepriklausančios mokyklos buvo

3 lentelè. Veiksniai, lemiantys mokytojų norą gauti daugiau sveikatos stiprinimo informacijos

$N=1247$. Modelio tikétinumo santykio chi kvadratas 36,81; lls. 4; $p<0,0005$; HosmerLemeshow testo chi kvadratas 4.04; llsk. 7; $p=0,775 ; R 2$ 0,0216

\begin{tabular}{|c|c|c|c|c|}
\hline Kintamieji & \begin{tabular}{|c|} 
ŠS \\
(ben- \\
drasis)
\end{tabular} & $\begin{array}{c}\text { ŠS } \\
\text { (kore- } \\
\text { guo- } \\
\text { tas) }\end{array}$ & PI (95\%) & p reikšmė \\
\hline $\begin{array}{l}\text { Mokytojo amžius } \\
50 \mathrm{~m} \text {. ir daugiau } \\
\text { Iki } 50 \mathrm{~m} \text {. }\end{array}$ & $\begin{array}{l}1,00 \\
1,38\end{array}$ & 1,35 & 1,$08 ; 1,70$ & 0,01 \\
\hline $\begin{array}{l}\text { Mokytojo išlavini- } \\
\text { mas } \\
\text { Aukštasis } \\
\text { Specialusis, aukš- } \\
\text { tesnysis }\end{array}$ & $\begin{array}{l}1,00 \\
1,32\end{array}$ & 1,06 & 0,$56 ; 2,03$ & 0,851 \\
\hline $\begin{array}{l}\text { Déstomas dalykas } \\
\text { Humanitarinis } \\
\text { Tikslusis } \\
\text { Kitas } \\
\end{array}$ & $\begin{array}{l}1,00 \\
1,01 \\
1,94\end{array}$ & $\begin{array}{l}1,04 \\
1,93\end{array}$ & $\begin{array}{l}0,79 ; 1,38 \\
1,46 ; 2,54\end{array}$ & $\begin{array}{c}0,758 \\
<0,0005\end{array}$ \\
\hline $\begin{array}{l}\text { Mokyklos priklau- } \\
\text { symas SSM tinklui } \\
\text { Priklauso } \\
\text { Nepriklauso } \\
\end{array}$ & $\begin{array}{l}1,00 \\
1,19\end{array}$ & 1,20 & 0,$95 ; 1,51$ & 0,122 \\
\hline
\end{tabular}

4 lentelè. Mokytojams reikalingiausios sveikatos stiprinimo informacijos temos $(n=1247)$

\begin{tabular}{|l|l|l|l|}
\hline Sveikatos stiprinimo tema & $\mathbf{n}$ & $\mathbf{\%}$ & $\mathbf{9 5 \%}$ PI \\
\hline Sveika mityba & 726 & 58,2 & 55,$5 ; 60,1$ \\
\hline $\begin{array}{l}\text { Protinė sveikata (streso įveikimas, de- } \\
\text { presija, netektys) }\end{array}$ & 615 & 49,3 & 46,$6 ; 52,1$ \\
\hline $\begin{array}{l}\text { Tabako, alkoholio ir kitų psichiką vei- } \\
\text { kiančių medžiagų vartojimo prevencija }\end{array}$ & 484 & 38,8 & 36,$2 ; 41,6$ \\
\hline Patyčių prevencija & 430 & 34,5 & 31,$2 ; 37,2$ \\
\hline Fizinis aktyvumas ir kūno kultūra & 406 & 32,6 & 30,$1 ; 35,2$ \\
\hline Darbo ir poilsio režimas & 331 & 26,5 & 24,$17 ; 29,1$ \\
\hline Lytiškumo ugdymas ir rengimas šeimai & 274 & 22,0 & 19,$8 ; 24,4$ \\
\hline Vartojimo kultūros ugdymas & 259 & 20,8 & 18,$6 ; 23,11$ \\
\hline Asmens higiena & 234 & 18,8 & 16,$7 ; 21,0$ \\
\hline $\begin{array}{l}\text { Nelaimingų atsitikimų ir traumų pre- } \\
\text { vencija }\end{array}$ & 203 & 16,3 & 14,$3 ; 18,4$ \\
\hline Žmogaus sauga & 130 & 10,4 & 8,$9 ; 12,2$ \\
\hline Užkrečiamų ligų prevencija & 116 & 9,3 & 7,$8 ; 11,6$ \\
\hline
\end{tabular}


suskirstytos ị didžiụjų miestų, miestų, miestelių, kaimų mokyklas, gimnazijas bei pagrindines mokyklas. Taikant sluoksninès imties sudarymo metodą, iš kiekvienos mokyklų grupès, pasinaudojus atsitiktinių skaičių generatoriumi, paprastos atsitiktinès atrankos būdu buvo atrinktas kiekvienos mokyklų grupės dydžiui proporcingas mokyklų skaičius. Mokyklos direktoriams atsisakius dalyvauti tyrime, atsitiktinai buvo įtrauktos kitos, tai pačiai grupei priklausančios mokyklos.

Apklausa buvo vykdoma nuo 2018 metu gegužès iki 2019 metų balandžio mėnesio. Tyrime dalyvavo 110 įvairių Lietuvos mokyklų mokytojai, kurie dèstè 9 ir 10 klasių mokiniams. Buvo išdalintos 1527 anketos, grąžintos 1273 užpildytos (atsako dažnis - 83,3 proc.). Tarp grąžintų anketų 26 buvo sugadintos (pažymèti keli atsakymo variantai, kai prašyta pažymėti vieną; užpildyta ne visa anketa, o tik jos dalis). Tyrimo analizei panaudotos 1247 tinkamai užpildytos mokytojų anketos.

Duomenų statistiniam apdorojimui naudotos Stata ir WinPepi statistinès programos. Paplitimo ịverčiams apskaičiuoti 95 proc. PI. Siekiant išsiaiškinti, kokie veiksniai daro reikšmingą poveikị informacijos apie mokinių sveikatos stiprinimą gavimui, skatina mokytojų norą gauti daugiau tokios informacijos, domètis ja bei atlikti informacijos paiešką, sudaryti logistinès regresijos modeliai. Jie buvo ịvertinti atlikus regresijos diagnostiką. Iš logistinès regresijos modelių gauti pakoreguoti šansų santykiai, apskaičiuoti jų 95 proc. PI. Skirtumas buvo laikomas statistiškai reikšmingu, kai $p \leq 0,05$.

Daugiau nei pusė apklaustų mokytojų dirbo gimnazijose arba kaimų ir miestelių mokyklose. Didžiąją dalį respondentų sudare moterys ir aukštaji išsilavinimą igiję mokytojai. Apklausti pedagogai pagal amžių pasiskirstè panašiai. Iš visų 1247 apklaustujjų 41,1 proc. sudarè dirbantieji SSM, kiti iprastinėse mokyklose. 29,8proc. mokytojų teigè dèstantys tiksliujų mokslų dalykus (tokius kaip chemija, fizika, biologija, matematika), panaši dalis dèste humanitarinius dalykus (pvz., istoriją, lietuvių kalbą, anglų kalbą), kiti - dalykus, kurių nebuvo galima priskirti nei humanitarinių, nei tiksliujų dalykų grupei, tokius kaip kūno kultūra, choreografija, technologijos, dailè ir panašius. Respondentų apibūdinimas pateikiamas 1 lentelèje.

\section{Tyrimo rezultatai ir jų aptarimas}

Mokytojų sveikatos stiprinimo informacijos poreikis. Tyrimo duomenimis, tik 44,3 proc. (95 proc. PI: 41,6; $47,1)$ mokytojų gauna pakankamai informacijos apie mokinių sveikatos stiprinimą. 5,0 proc. (95 proc. PI: 47,$9 ; 6,3)$ respondentu pakankamo informacijos kiekio negauna, o 50,7 proc. (95 proc. PI: 47,9; 53,5) gauna tik iš dalies. Tai, kad mokytojams trūksta informacijos apie sveikatos stiprinimą, patvirtino 2013 metais Mykolo Romerio universiteto ir Lietuvos edukologijos universiteto mokslininkų atlikto tyrimo rezultatai, atkleidę, kad tik 37,9 proc. mokytojų mano, jog yra pasirengę ugdyti mokinių sveiką gyvenseną [13].

Analizuojant veiksnius, darančius poveiki informacijos gavimui, nustatyta, kad aukštaji išsilavinimą igijusių mokytojų šansas gauti pakankamą sveikatos stiprinimo informacijos kiekį buvo 2,85 kartų didesnis, nei turinčių specialųji ar aukštesnijj išsilavinimą. Reikšmingai daugiau nei 2 kartus didesnị šansą gauti pakankamą informacijos kiekị turejo SSM mokytojai, negu dirbantys ịprastinèse mokyklose. Rezultatai atskleide, kad pakankamas sveikatos stiprinimo informacijos gavimas buvo reikšmingai susijęs su ugdymo įstaigos vieta: kaimų bei miestelių mokyklų mokytojų šansas gauti pakankamai tokios informacijos buvo 29 proc. didesnis, negu miestų ir didžiųų miestų mokyklų mokytojų (2 lentelè).

43,3 proc. (95 proc. PI: 40,6; 46,1) mokytojų teigè norintys gauti daugiau informacijos apie mokinių sveikatos stiprinimą. 56,7 proc. (95 proc. PI: 53,9; 59,4) respondentų nenorejo gauti tokios informacijos, arba teigè norintys jos gauti tik šiek tiek daugiau.

Nagrinejjant veiksnius, lemiančius mokytojų norą gauti daugiau informacijos apie mokinių sveikatos stiprinimą, nustatyta, kad humanitarinius dalykus dėstančių mokytojų šansas siekti daugiau sveikatos stiprinimo informacijos yra 94 proc. didesnis, nei kitų dalykų mokytojų. Taip pat nustatyta, kad jaunesnių nei 50 metų mokytojų šansas norèti daugiau informacijos yra 1,35 karto didesnis, nei vyresnio amžiaus mokytojų. Šansas norèti daugiau informacijos buvo susijęs ir su mokytojų išsilavinimu, mokyklos priklausymu SSM tinklui, tačiau šie skirtumai nebuvo statistiškai reikšmingi (3 lentelè).

Didžiausia dalis respondentų ( 58,2 proc.) teigè, kad mokytojams informacija sveikos mitybos tema yra reikalingiausia (4 lentelè). Nors tyrimas atskleide, kad beveik pusei mokytojų (49,3 proc.) reikalinga informacija apie protinę sveikatą, literatūros, skirtos psichikos sveikatos ugdymui, Vilniaus pedagoginio universiteto ataskaitos duomenimis, trūksta didelei daliai mokytojų (daugiau nei 40 proc. apklaustujų) [14].

Didelè dalis mokytojų (38,8 proc.) temą „Tabako, alkoholio ir kitu psichiką veikiančių medžiagų vartojimo prevencija“ ivvardijo kaip temą, kurios informacija mokytojams reikalingiausia. Tyrimo duomenimis, mokytojams mažiausiai reikalinga informacija nelaimingų atsitikimų ir traumų prevencijos, žmogaus saugos bei užkrečiamųų ligų prevencijos temomis (4 lentelè).

Mokytojų domėjimasis sveikatos stiprinimo informacija bei jos paieška. Tyrimo rezultatai parode, kad didžiają dalị mokytojų 71,6 proc. (95 proc. PI: 69,$1 ; 74,1)$ 
domina mokinių sveikatos stiprinimo informacija. Analizuojant veiksnius, nuo kurių priklauso mokytojų domėjimasis sveikatos stiprinimo informacija, nustatyta, kad statistiškai reikšmingai didesnį šansą domètis šia informacija turejo moterys nei vyrai, bei kitus, nei humanitarinius ar tiksliuosius dalykus dėstantys mokytojai. Taip pat nustatyta, kad darbas SSM, palygintas su darbu SSM tinklui nepriklausančioje mokykloje, 1,45 karto padidina domè-

5 lentelè. Veiksniai, lemiantys mokytojų doméjimąsi sveikatos stiprinimo informacija

$N=1247$. Modelio tikètinumo santykio chi kvadratas 29,61; lls. 5; $p<0,0005$; Hosmer ir Lemeshow testo chi kvadratas 5,40; llsk. 8; $p=0,7136$; R2 0,0199

\begin{tabular}{|c|c|c|c|c|}
\hline Kintamieji & \begin{tabular}{|l|} 
ŠS \\
( b e n - \\
drasis) \\
\end{tabular} & $\begin{array}{l}\text { ŠS (ko- } \\
\text { reguo- } \\
\text { tas) }\end{array}$ & PI (95\%) & $\begin{array}{l}\text { p reikš- } \\
\text { mé }\end{array}$ \\
\hline $\begin{array}{l}\text { Lytis } \\
\text { Vyras } \\
\text { Moteris }\end{array}$ & $\begin{array}{l}1,00 \\
1,38\end{array}$ & 1,56 & 1,$09 ; 2,23$ & 0,014 \\
\hline $\begin{array}{l}\text { Dėstomas dalykas } \\
\text { Humanitarinis } \\
\text { Tikslusis } \\
\text { Kitas } \\
\end{array}$ & $\begin{array}{l}1,00 \\
1,15 \\
1,66 \\
\end{array}$ & $\begin{array}{l}1,16 \\
1,79 \\
\end{array}$ & $\begin{array}{l}0,87 ; 1,56 \\
1,31 ; 2,47\end{array}$ & $<0,0005$ \\
\hline $\begin{array}{l}\text { Mokyklos vieta } \\
\text { Miestas, didysis mies- } \\
\text { tas } \\
\text { Kaimas, miestelis }\end{array}$ & $\begin{array}{l}1,00 \\
1,31\end{array}$ & 1,26 & 0,$98 ; 1,62$ & 0,066 \\
\hline $\begin{array}{l}\text { Mokyklos priklausy- } \\
\text { mas SSM tinklui } \\
\text { Nepriklauso } \\
\text { Priklauso }\end{array}$ & $\begin{array}{l}1,00 \\
1,48\end{array}$ & 1,45 & 1,$17 ; 1,88$ & 0,005 \\
\hline
\end{tabular}

6 lentelè. Veiksniai, lemiantys mokytojų sveikatos stiprinimo informacijos paiešką

$N=1247$. Modelio tikétinumo santykio chi kvadratas 37,87; lls. 5; $p<0,0005$; HosmerLemeshow testo chi kvadratas 3,72; llsk. 8; $p=0,88 ; R 2$ 0,023

\begin{tabular}{|c|c|c|c|c|}
\hline Kintamieji & \begin{tabular}{|l|} 
ŠS \\
(bend- \\
rasis) \\
\end{tabular} & $\begin{array}{l}\text { ŠS (ko- } \\
\text { reguo- } \\
\text { tas) }\end{array}$ & \begin{tabular}{|l} 
PI \\
$(95 \%)$
\end{tabular} & $\begin{array}{l}\text { p reikš- } \\
\text { mé }\end{array}$ \\
\hline $\begin{array}{l}\text { Mokytojo išlavinimas } \\
\text { Specialusis, aukštesny- } \\
\text { sis } \\
\text { Aukštasis }\end{array}$ & $\begin{array}{l}1,00 \\
1,91\end{array}$ & 2,54 & 1,$32 ; 4,88$ & 0,005 \\
\hline $\begin{array}{l}\text { Dėstomas dalykas } \\
\text { Humanitarinis } \\
\text { Tikslusis } \\
\text { Kitas } \\
\end{array}$ & $\begin{array}{l}1,00 \\
1,17 \\
1,57 \\
\end{array}$ & $\begin{array}{l}1,14 \\
1,68 \\
\end{array}$ & $\begin{array}{l}0,86 ; 1,50 \\
1,25 ; 2,25 \\
\end{array}$ & $\begin{array}{l}0,365 \\
<0,0005\end{array}$ \\
\hline $\begin{array}{l}\text { Mokyklos vieta } \\
\text { Miestas, didysis miestas } \\
\text { Kaimas, miestelis }\end{array}$ & \begin{tabular}{|l|}
1,00 \\
1,58 \\
\end{tabular} & 1,57 & 1,$25 ; 1,99$ & $<0,0005$ \\
\hline $\begin{array}{l}\text { Mokyklos priklausy- } \\
\text { mas SSM tinklui } \\
\text { Nepriklauso } \\
\text { Priklauso }\end{array}$ & \begin{tabular}{|l|}
1,00 \\
1,36 \\
\end{tabular} & 1,31 & 1,$03 ; 1,66$ & 0,027 \\
\hline
\end{tabular}

jimosi sveikatos stiprinimo informacija šansą (5 lentelè). Nustatyta, kad daugiau nei pusè (62,9 proc.) respondentu (95 proc. PI: 60,$2 ; 65,5)$ ieškojo informacijos apie mokinių sveikatos stiprinimą. Beveik visi (97,3 proc.; 95 proc. PI: 95,9; 98,2) nurodè radę ieškotą informaciją. Analizuojant veiksnius, lemiančius informacijos paiešką, nustatyta, kad aukštajị išsilavinimą igiję mokytojai turi net 2,54 karto didesnį šansą ieškoti informacijos apie mokinių sveikatos stiprinimą, nei specialųji ar aukštesniji išsilavinimą turintys mokytojai. Didesnį šansą mokytojams patiems ieškoti informacijos apie mokinių sveikatos stiprinimą teikia ir mokyklos

7 lentelè. Mokiniams reikalingiausios sveikatos stiprinimo informacijos temos

\begin{tabular}{|l|l|l|l|}
\hline Sveikatos stiprinimo tema & n & proc. & PI (95\%) \\
\hline Sveika mityba & 725 & 58,1 & 55,$4 ; 60,1$ \\
\hline $\begin{array}{l}\text { Tabako, alkoholio ir kitų psichiką vei- } \\
\text { kiančių medžiagų vartojimo prevencija }\end{array}$ & 616 & 49,4 & 46,$6 ; 52,2$ \\
\hline $\begin{array}{l}\text { Protinè sveikata (streso įveikimas, de- } \\
\text { presija, netektys) }\end{array}$ & 615 & 49,3 & 46,$5 ; 52,1$ \\
\hline Patyčių prevencija & 496 & 39,8 & 37,$1 ; 42,5$ \\
\hline Fizinis aktyvumas ir kūno kultūra & 490 & 39,3 & 36,$6 ; 42,0$ \\
\hline Lytiškumo ugdymas ir rengimas šeimai & 254 & 20,4 & 18,$2 ; 22,7$ \\
\hline Darbo ir poilsio režimas & 227 & 18,2 & 16,$2 ; 20,4$ \\
\hline Asmens higiena & 190 & 15,2 & 13,$6 ; 17,3$ \\
\hline $\begin{array}{l}\text { Nelaimingų atsitikimų ir traumų pre- } \\
\text { vencija }\end{array}$ & 178 & 14,3 & 12,$4 ; 16,3$ \\
\hline Vartojimo kultūros ugdymas & 173 & 13,9 & 12,$1 ; 15,9$ \\
\hline Užkrečiamų ligų prevencija & 58 & 4,7 & 3,$6 ; 5,9$ \\
\hline Žmogaus sauga & 48 & 3,8 & 2,$9 ; 5,1$ \\
\hline
\end{tabular}

8 lentelè. Mokiniams trūkstamos sveikatos stiprinimo informacijos temos

\begin{tabular}{|l|l|l|l|}
\hline Sveikatos stiprinimo tema & n & proc. & PI (95\%) \\
\hline $\begin{array}{l}\text { Protiné sveikata (streso ịveikimas, } \\
\text { depresija, netektys) }\end{array}$ & 689 & 55,3 & 52,$5 ; 58,0$ \\
\hline Vartojimo kultūros ugdymas & 415 & 33,3 & 30,$7 ; 35,9$ \\
\hline $\begin{array}{l}\text { Lytiškumo ugdymas ir rengimas šei- } \\
\text { mai }\end{array}$ & 394 & 31,6 & 29,$1 ; 34,2$ \\
\hline Darbo ir poilsio režimas & 375 & 30,1 & 27,$6 ; 32,68$ \\
\hline Sveika mityba & 313 & 25,1 & 22,$8 ; 27,6$ \\
\hline $\begin{array}{l}\text { Tabako, alkoholio ir kitų psichiką } \\
\text { veikiančių medžiagų vartojimo pre- } \\
\text { vencija }\end{array}$ & 247 & 19,8 & 17,$7 ; 22,1$ \\
\hline Užkrečiamujų ligų prevencija & 223 & 17,9 & 15,$9 ; 20,1$ \\
\hline $\begin{array}{l}\text { Nelaimingų atsitikimų ir traumų pre- } \\
\text { vencija }\end{array}$ & 213 & 17,1 & 15,$1 ; 19,3$ \\
\hline Asmens higiena & 203 & 16,3 & 14,$3 ; 18,4$ \\
\hline Patyčių prevencija & 194 & 15,6 & 13,$7 ; 17,7$ \\
\hline Fizinis aktyvumas ir kūno kultūra & 153 & 12,3 & 10,$6 ; 14,2$ \\
\hline Žmogaus sauga & 54 & 4,3 & 3,$3 ; 5,6$ \\
\hline
\end{tabular}


buvimas SSM tinkle. Rezultatai atskleide, kad informacijos paieška reikšmingai susijusi su mokyklos vieta bei dėstomu dalyku (6 lentelè).

Mokytojų nuomonė apie sveikatos stiprinimo informacijos poreikį jų mokiniams. Atlikto tyrimo duomenys parodè daugumos mokytojų nuomonę apie jų mokiniams reikalingiausią sveikatos stiprinimo informaciją. Tai sveikos mitybos, tabako, alkoholio bei kitų psichiką veikiančių medžiagų vartojimo prevencija ir protinè sveikata. Mokytojų nuomone, mažiausiai jų mokiniams reikalinga informacija vartojimo kultūros, užkrečiamujų ligų prevencijos ir žmogaus saugos temomis (7 lentelè).

Daugiau nei pusė apklaustų mokytojų ( 55,3 proc.) nurodè, kad jų mokiniams trūksta informacijos protinès sveikatos tema. Apie trečdalis pedagogų nurodè, kad mokiniams trūksta informacijos vartojimo kultūros $(33,3$ proc.) bei lytiškumo ugdymo ir rengimo šeimai $(31,6$ proc.) temomis. Mažiausiai mokytojų teigè, kad mokiniams trūksta informacijos fizinio aktyvumo ir kūno kultūros (12,3 proc.) bei žmogaus saugos ( 4,3 proc.) temomis (8 lentelè).

\section{Išvados}

1. Beveik pusė mokytojų gauna pakankamai informacijos apie mokinių sveikatos stiprinimą. Šansą gauti pakankamą informacijos kiekį reikšmingai didina mokytojų aukštasis išsilavinimas, mokyklos priklausymas SSM tinklui bei darbas kaimų, miestelių mokyklose.

2. Daugiau nei 40 proc. mokytojų nori gauti daugiau informacijos apie mokinių sveikatos stiprinimą. Šis noras reikšmingai susijęs su mokytojų amžiumi bei dèstomu dalyku.

3. Sveikos mitybos bei protinès sveikatos temomis pateikta sveikatos stiprinimo informacija mokytojams yra reikalingiausia.

4. Didžiają dalị mokytojų domina informacija apie mokinių sveikatos stiprinimą. Domejjimosi šansą reikšmingai didina moteriška lytis, kitų, nei humanitarinių ir tiksliųjų, dalykų dėstymas bei darbas mokykloje, kuri priklauso SSM tinklui.

5. Daugiau nei 60 proc. mokytojų patys ieškojo informacijos apie mokinių sveikatos stiprinimą. Informacijos paieška reikšmingai susijusi su mokytojų išsilavinimu, dèstomu dalyku, mokyklos vieta bei priklausymu SSM tinklui.

6. Daugiau nei pusès mokytojų nuomone, sveikos mitybos tema pateikta informacija reikalingiausia jų mokiniams. Labiausiai mokiniams trūksta informacijos apie protinę sveikatą.

\section{Literatūra}

1. World health organisation. European strategy for child and adolescent health and development. 2005; 1-3. http://www.
euro.who.int/_data/assets/pdf_file/0003/81831/E91655.pdf

2. Gurevičius R. Vaiku sveikatos metus palydint. Visuomenès sveikata, 2014;4(67):5-8. : http://www.hi.lt/uploads/pdf/visuomenes\%20sveikata/VS\%202014\%204(67).pdf

3. Nabe-Nielsen K, Krølner R, Mortensen LH, et al. Health promotion in primary and secondary schools in Denmark: time trends and associations with schools' and students' characteristics. BMC Public Health 2015;7:1-10. https://www.ncbi.nlm.nih. gov/pubmed/25885694 https://doi.org/10.1186/s12889-015-1440-z

4. Mclsaac JL, Penny L T, Ata N, et al. Evaluation of a health promoting schools program in a school board in Nova Scotia, Canada. Preventive medicine reports. 2017;5:279-284. https:// www.ncbi.nlm.nih.gov/pmc/articles/PMC5279859/\#bb0030 https://doi.org/10.1016/j.pmedr.2017.01.008

5. The Ottawa charter for health promotion. World health organisation, 1986. http://www.who.int/healthpromotion/conferences/ previous/ottawa/en

6. Lietuvos Respublikos švietimo ir mokslo ministro $2016 \mathrm{~m}$. spalio 25 d. įsakymas Nr. V-941 „Dèl Sveikatos ir lytiškumo ugdymo bei rengimo šeimai bendrosios programos". https://www.e-tar. 1t/portal/1t/legalAct/b10c19209a9a11e69ad4c8713b612d0f

7. Sveikatos stiprinimas mokyklose. Metodinès rekomendacijos. Valstybinis aplinkos sveikatos centras, 2008:1-32. http:// www.smlpc.lt/media/file/Skyriu_info/Vaiku_sveikata/SSM/ Publikacijos_leidiniai/Sveikatos_stiprinimas_mokyklos-metodines_rekomendacijos.pdf

8. The Odense statement: our $\mathrm{ABC}$ for equity, education and health.2013:1-5. https://www.schoolsforhealth.org/sites/default/ files/editor/conference $\% 20$ statements/Odense $\% 20$ Statement/ english-odense-statement.pdf

9. Paurienė V., Dovidauskaitė D. Mokinių sveikata: kaip ją išsaugoti? Švietimo ir mokslo ministerija. Švietimo problemos analize, 2015;11(135):1-12. http://www.nmva.smm.lt/wp-content/ uploads/2012/12/Mokini\%C5\%B3-sveikata-kaip-j\%C4\%85i\%C5\%A1saugoti.pdf

10. Česnavičienė J., Gudžinskienè V. Mokytojų, kaip sveikatos ugdytojų, vaidmuo ir jų patirtys igyvendinant integruotaji sveikatos ugdymą. Andragogika, 2014;1(5):27-43.

https://doi.org/10.15181/andragogy.v5i0.961

11. UNICEF tyrimas: lietuviai savo vaikams skiria 7 minutes per parą. Socialinès apsaugos ir darbo ministerija, 2009. http://infolex. 1t/portal/start_visuom.asp?act $=$ news $\&$ Tema $=44 \&$ str $=27677$

12. Sveikatą stiprinančių mokyklų veiklos vertinimo praktinis vadovas. Valstybinis aplinkos sveikatos centras, 2009:1-236. http://www.smlpc.lt/media/file/Skyriu_info/Vaiku_sveikata/ SSM/Publikacijos_leidiniai/Veikslos_vertinimo_praktinis_vadovas.pdf

13. Gudžinskienė V., Česnavičienė J. Mokytojų žinios apie sveikatą ir sveiką gyvenseną kaip mokinių sveikos gyvensenos ugdymo prielaida. Socialinis darbas, 2013;12(1):121-136. https://repository.mruni.eu/bitstream/handle/007/10599/14227. pdf? sequence $=1$ \&isAllowed $=\mathrm{y}$. 
14. Gudžinskienė V., Česnavičienė J., Suboč V. Sveikos gyvensenos ugdymas mokyklose. Tyrimo ataskaita. Švietimo ir mokslo ministerija, 2007; 1-115. https:/www.smm.lt/uploads/documents/ kiti/SVEIKOS\%20GYVENSENOS\%20UGDYMAS\%20 MOKYKLOSE.pdf

TEACHERS' OPINION ABOUT THE NEED FOR HEALTH PROMOTION INFORMATION FOR THEM AND THEIR PUPILS

\section{R. Maceinaitė, G. Šurkienė, R. Sketerskienė, M. Butikis}

Keywords: teachers, pupils, health promotion, need for information on health promotion.

Summary

School is the most appropriate place for health promotion of pupils, which enables then to increase control over, and to improve, their health. Health promotion only gives the best results when not only pupils but also their teachers are involved in the process, it is obvious that the success of health promotion depends on the teacher's attitude towards this process and his knowledge in this field. Aim of the study - to assess teachers' perceptions of the need for information on health promotion for themselves and their pupils. 1247 teachers from 110 different schools who were teaching ninth and tenth graders in Lithuania were surveyed. Estimate of prevalence were calculated at $95 \% \mathrm{CI}$, logistic regression models were concluded, 95\% CIs of adjusted odds ratio were calculated. The results of the survey revealed that $44.3 \%$ of teachers receives sufficient amount of information on health promotion of pupils and that $43.3 \%$ of respondents wants more information on this subject. The odds of getting enough information on pupils health promotion are significantly related to teachers education, schools membership in Health Promoting Schools Network (HPSN) and location of school, the odds of wishing to get more information - with teachers age and the subject teacher teaches. Study shows that the most necessary information for teachers is information about healthy diet. They believe that this information is also most relevant to their pupils. In the opinion of the teachers, their pupils lack information on mental health. The results showed that $71.6 \%$ of the respondents were interested in information about health promotion of pupils and also that $62.9 \%$ of them were looking for information on this subject themselves. Interest in this subject is significantly related to gender, the subject taught by teacher, and schools membership in HPSN, searching for information on health promotion of pupils is related to teacher education, subject that teacher teaches, location of school, and schools membership in HPSN.

Correspondence to: ruta.maceinaite@gmail.com

Gauta 2019-12-09 